\title{
WPROWADZENIE DOLNOŚLĄSKIEGO KOMENDANTA WOJEWÓDZKIEGO PSP
}

W dwudziestą piątą rocznicę uchwalenia ustaw o ochronie przeciwpożarowej i o PSP do czytelników trafia praca zbiorowa poświęcona tamtym historycznym wydarzeniom. Jej znaczenie wynika przede wszystkim z faktu, że gruntowna przebudowa struktur polskiej straży pożarnej wpisuje się, wraz z wieloma innymi systemowymi przemianami, obejmującymi wszystkie dziedziny życia, w nową polską rzeczywistość społeczno-polityczną. Z tego punktu widzenia można powiedzieć, że praca ta jest swoistym suplementem do najnowszej historii polskiej straży pożarnej, a także polskich przemian ustrojowych.

Konstatacja ta jest niewątpliwie nadrzędna i uzasadnia obecność tej pozycji na rynku wydawniczym. Jednocześnie trudno nie zauważyć, że przecież temat źródeł i okoliczności powstania ustaw pożarniczych, i utworzenia samej PSP, był przedmiotem wielu publikacji. Płynie stąd logiczny wniosek, że kolejna publikacja będzie miała uzasadnienie, tylko gdy wniesie coś nowego do już istniejącego dorobku naukowego i publicystycznego. Dlatego też niezbędna jest uczciwa odpowiedź na pytanie o powody motywujące autorów do napisania niniejszej książki.

Tak patrząc, trzeba odwołać się do wielokrotnie potwierdzonej empirycznie reguły, że indywidualne oceny zdarzeń i procesów składających się na przełomowe decyzje i fakty są zawsze zróżnicowane, a nierzadko bywa, że wręcz przeciwstawne. Upublicznienie szerokiej palety tych różnorodnych ocen i opinii warunkuje zatem poznanie wszystkich okoliczności towarzyszących określonemu procesowi. A skoro tak, to pogłębiona wiedza determinuje sformułowanie zobiektywizowanej, a więc najbliższej prawdy oceny danego procesu. Dzięki temu następuje też prawidłowe umiejscowienie ważnych historycznie zdarzeń w szerokim nurcie przemian, składających się na wielką przebudowę całości życia społecznego i państwowego.

Niniejsza praca zbiorowa jest kompilacją wielu indywidualnych i zróżnicowanych ocen sformułowanych, co ważne, przez uczestników wydarzeń sprzed ćwierć wieku. I na tym polega wartość tej książki, choć przecież nie tylko. Trzeba bowiem jednocześnie wskazać, że choć w minionych latach było wiele publikacji poświęconych omawianym procesom, to nie zawsze, niestety, spełniały one warunek historycznej zgodności z rzeczywistością. A zatem pojawiła się naturalna 
potrzeba, a nawet wręcz konieczność, odniesienia się do tamtych zdarzeń i faktów nie tylko z rocznicowej okazji, lecz także aby ukazać je w zgodzie z rzeczywistością i w konsekwencji w należytej perspektywie historycznej.

Oczywiście w kontekście obecnej publikacji jawi się i inne pytanie, a mianowicie czy stanowi ona postawienie swoistej kropki nad ,i” w dyskusji o wydarzeniach sprzed dwudziestu pięciu lat. Otóż niewątpliwie nie, ponieważ mijający czas obiektywizuje oceny i wydarzenia, pozwala na uzyskanie niezbędnego dystansu, jak też, w ślad za tym, uzasadnia formułowanie nowych ocen oraz wniosków. Być może w przyszłości pojawią się nowe fakty, które wzbogacą naszą wiedzę i ukażą omawianą problematykę w nowym świetle.

Niewątpliwe jednak książka ta jest ważnym przyczynkiem do ukazania najnowszej historii polskiej straży pożarnej i polskich przemian ustrojowych w całej jej złożoności. Zważywszy zaś, że miejsce i rola PSP w umacnianiu państwa polskiego i jego obywateli sukcesywnie wzrasta, potwierdzając tym samym trafność rozwiązań przyjętych ćwierć wieku temu, uzasadniona jest i taka oto refleksja. Tak jak przed laty warto było bić się o nowy kształt polskiej straży pożarnej, tak dziś trzeba zadbać o to, aby wiedza o tym, jak naprawdę do tego doszło, jakie okoliczności towarzyszyły tym zdarzeniom i kto tak naprawdę położył swoją cegiełkę w budowaniu tego filaru bezpieczeństwa państwa i obywateli, była pełna i rzetelna.

st. bryg. mgr inż. Adam Konieczny Dolnośląski Komendant Wojewódzki Państwowej Straży Pożarnej 